Artikel Penelitian

\title{
Ekstrak Etanol Daun Belimbing Wuluh (Averrhoa bilimbi) sebagai Antioksidan dan Antiinflamasi
}

\section{Ethanol Extracts of Averrhoa Bilimbi Leaf Demonstrated Antioxidative and Anti-inflammatory Activity}

\section{Hasim $^{1 *}$, Yupi Yulianita Arifin ${ }^{1}$, Dimas Andrianto ${ }^{1}$, Didah Nur Faridah ${ }^{2}$}

${ }^{1}$ Departemen Biokimia, Fakultas Matematika dan IImu Pengetahuan Alam, Institut Pertanian Bogor, Bogor

${ }^{2}$ Departemen Ilmu dan Teknologi Pangan, Fakultas Teknologi Pertanian, Institut Pertanian Bogor, Bogor

*Korespondensi dengan penulis (hasim@apps.ipb.ac.id)

Artikel ini dikirim pada tanggal 20 januari 2019 dan dinyatakan diterima tanggal 3 Agustus 2019. Artikel ini juga dipublikasi secara online melalui https://ejournal2.undip.ac.id/index.php/jatp. Hak cipta dilindungi undang-undang. Dilarang diperbanyak untuk tujuan komersial.

Diproduksi oleh Indonesian Food Technologists $®$ (C2019

\begin{abstract}
Abstrak
Belimbing wuluh merupakan tanaman jenis buah dan obat tradisional. Tanaman belimbing wuluh sudah sering dimanfaatkan masyarakat salah satunya untuk mengobati penyakit seperti batuk dan radang rektum. Tujuan penelitian ini adalah menguji senyawa fitokimia, menganalisis kandungan total fenolik dan flavonoid, serta aktivitas antioksidan dan antiinflamasi secara in vitro pada ekstrak etanol daun belimbing wuluh. Metode yang dilakukan pada penelitian ini adalah ekstraksi daun belimbing wuluh, skrining fitokimia, perhitungan total fenol dan flavonoid, uji aktivitas antioksidan, dan uji aktivitas antiinflamasi. Senyawa fitokimia yang terkandung pada ekstrak etanol daun belimbing wuluh adalah saponin, tanin, steroid, flavonoid, dan alkaloid. Kandungan total fenolik dan flavonoid ekstrak etanol daun belimbing wuluh secara berturut-turut sebesar 39,03 dan 97,28 $\mu \mathrm{g} \mathrm{QE} / \mathrm{mg}$. Ekstrak etanol daun belimbing wuluh memiliki aktivitas antioksidan yang tergolong sangat kuat, sementara aktivitas antiinflamasinya terutama ditunjukkan pada konsentrasi ekstrak $200 \mu \mathrm{g} / \mathrm{ml}$, memiliki nilai persen inhibisi hemolisis yang paling tinggi. Kesimpulannya, ekstrak etanol daun belimbing wuluh dapat menjadi salah satu sumber antioksidan dan antiinflamasi alami.
\end{abstract}

Kata kunci: antiinflamasi, antioksidan, belimbing wuluh, etanol

\begin{abstract}
Averrhoa bilimbi, a fruit-bearing plant, has been traditionally used for medicinal purposes such as treatment of cough and rectal inflammation. In this current work, ethanol extract of Averrhoa bilimbi leaf was analyzed, with regard to phytochemical composition, i.e. total phenolic, and flavonoid, antioxidant activity, and in vitro antiinflammation activity. Extraction of carambola leaves, phytochemical screening, total phenolic and flavonoid contens, assay of antioxidant activity, and assay of anti-inflammatory activity were done in this research. As a result, the leaf extract positively contained some phytochemical compounds, i.e. saponin, tannin, steroid, flavonoid, and alkaloid. Furthermore, total phenolic and flavonoid of the leaf extract was found at 39.03 and $97.28 \mu \mathrm{g} Q \mathrm{Eg}$ extract, respectively. Additionally, antioxidant activity of the leaf extract was classified as very strong, while its antiinflammatory feature at extract concentration of $200 \mu \mathrm{g} / \mathrm{ml}$ exhibited the highest inhibition of hemolysis. In summary, the ability of Averrhoa bilimbi leaf ethanol extracts to act as antioxidative and anti-inflammatory agents was determined and this may open the use for natural antioxidant and anti-inflammatory agents.
\end{abstract}

Keywords: Averrhoa bilimbi leaf, anti-inflammation, antioxidant, ethanol extract

\section{Pendahuluan}

Non Communicable Disease (NCD) atau yang lebih umum dikenal dengan istilah penyakit tidak menular masih menjadi penyebab utama kematian di tingkat global. Pada tahun 2012, dari total 56 juta kematian yang terjadi di dunia, 38 juta diantaranya disebabkan oleh NCD. Sebesar $40 \%$ dari kasus kematian akibat NCD tersebut terjadi pada individu di bawah usia 70 tahun (WHO, 2014). Menurut Badan Kesehatan Dunia WHO, kematian akibat NCD diperkirakan dapat terus meningkat di seluruh dunia dimana peningkatan terbesar terjadi di negara-negara dengan tingkat ekonomi rendah dan menengah (Kemenkes RI, 2012). Di Indonesia, NCD menyumbangkan angka sebesar $71 \%$ dari total angka kematian (WHO, 2014).

Salah satu penyebab penyakit tidak menular adalah terjadinya stress oksidatif di dalam tubuh yang merupakan kondisi ketidakseimbangan antara senyawa radikal bebas dan antioksidan. Senyawa radikal bebas ini terbentuk secara alami selama proses metabolisme tubuh. Pembentukan senyawa radikal bebas dalam tubuh yang tidak terkendali atau melebihi batas akan menyebabkan kerusakan oksidasi sel yang mengarah terhadap resiko terkena penyakit degeneratif, seperti aterosklerosis, gagal jantung, kanker dan alzheimer (Landete, 2013).

Fungsi utama antioksidan adalah untuk menghentikan atau memutus reaksi berantai dari radikal bebas yang terdapat dalam tubuh serta menetralkan radikal bebas sehingga dapat melindungi sistem biologi tubuh dari efek merugikan yang timbul dari proses maupun reaksi yang menyebabkan oksidasi berlebihan (Berdanier et al., 2008). Tubuh secara alami menghasilkan antioksidan endogen intrasel yang terdiri atas enzim-enzim yang disintesis oleh tubuh, seperti 
superoksida dismutase, katalase, dan glutation peroksidase (Werdhasari, 2014). Enzim-enzim yang berfungsi sebagai antioksidan endogen dapat menurun aktivitasnya pada saat keadaan patologik, diantaranya akibat terbentuknya radikal bebas dalam jumlah berlebih. Oleh karena itu jika terjadi peningkatan radikal bebas dalam tubuh dibutuhkan antioksidan eksogen dalam jumlah yang lebih besar untuk mengeliminir dan menetralisir efek radikal bebas. Upaya mempertinggi status antioksidan dalam tubuh dapat dilakukan dengan mengkonsumsi bahan pangan yang mengandung zatzat gizi antioksidan maupun antioksidan non gizi (komponen bioaktif) sehingga kadar antioksidan dalam tubuh dapat dipertahankan tetap tinggi (Valko et al., 2007). Konsumsi bahan pangan kaya antioksidan perlu ditingkatkan oleh masyarakat untuk menekan tingginya prevalensi penyakit degeneratif.

Salah satu sumber dari pembentukan radikal bebas dalam tubuh adalah saat terjadinya proses inflamasi Inflamasi merupakan suatu respon protektif lokal yang timbul karena kerusakan pada jaringan yang disebabkan oleh trauma fisik, kimiawi maupun mikrobiologi (Agustina et al., 2015). Obat antiinflamasi yang umum digunakan saat ini dinilai memiliki efek samping yang cukup serius seperti penurunan imunitas terhadap infeksi, osteoporosis, serta bersifat hiperglikemik, gangguan lambung dan ginjal, serta anemia yang kemudian memicu pengembangan antiinflamasi yang berasal dari tanaman (Rinayanti et al., 2014).

Belimbing wuluh disebut juga belimbing asam adalah sejenis pohon yang diperkirakan berasal dari kepulauan Maluku (Thomas, 2007). Belimbing wuluh merupakan tanaman jenis buah dan obat tradisional. Ekstrak metanol buah belimbing wuluh diantaranya mengandung alkaloid, saponin, tanin, flavonoid, fenol, dan triterpenoid. Selain itu juga diketahui bahwa ekstrak metanol buah belimbing wuluh memiliki aktivitas antioksidan (Hasanuzzaman et al., 2013). Daun belimbing wuluh mengandung senyawa flavonoid, fenol, alkaloid, tanin, dan kumarin (Valsan dan Raphael, 2016). Penelitian sebelumnya menunjukkan bahwa ekstrak etanol daun $A$. bilimbi dan fraksinya memiliki efek hipoglikemik dan hipolipidemik pada tikus model diabetes tipe I (Pushparaj et al., 2000). Ekstrak etanol yang telah dimurnikan dari daun belimbing wuluh mempunyai potensi untuk dikembangkan menjadi obat antihipertensi, karena memberikan efek penurunan tekanan darah secara signifikan terhadap hewan uji kucing (Hernani et al., 2009). Hingga saat ini masih sedikit literatur mengenai analisis fitokimia dari daun blimbing wuluh ini terutama yang berkaitan dengan antioksidan dan antiinflamasi. Oleh karena itu, tujuan penelitian ini adalah menguji senyawa fitokimia, menganalisis kandungan total fenol dan flavonoidnya, serta menguji aktivitas antioksidan dan antiinflamasi secara in vitro dari ekstrak etanol daun belimbing wuluh sebagai upaya untuk menemukan salah satu sumber antioksidan alami yang juga bermanfaat sebagai antiinflamasi.

\section{Materi dan Metode}

Materi

Alat-alat yang digunakan dalam penelitian ini adalah spektrofotometer UV-Vis (Thermo Genesys 10 UV, Amerika Serikat), peralatan gelas, neraca analitik (kenko, Jepang), rotary evaporator (Eyela, Jepang), pH meter (Hanna, Amerika Serikat), penangas air (Sanyo Rikagaku-Kikai, Jepang dan Memmert tipe W600, Jerman), lempeng pemanas-pengaduk (Gerhardt, Amerika Serikat), sentrifus tipe 1200 (Hettich Universal, Jerman), ultrasonikator (Decon model FS Major, Inggris), kuvet (sigma C-8550, Amerika Serikat), dan pipet mikro (Rainin Pipet Lite LS, Amerika Serikat), oven NDO-700 (Eyele, Jepang) dan pompa vakum Welch 1399 (Welch, Amerika Serikat).

Bahan utama yang digunakan adalah digunakan adalah daun belimbing wuluh yang tidak terlalu tua juga tidak terlalu muda (teksturnya tidak terlalu licin dan tidak terlalu tebal, tetapi juga tidak kesat, serta belum terdapat warna bercak kuning yang menandakan daun sudah mulai menua) yang berasal dari daerah Ciselang, Cianjur, Jawa Barat. Pelarut yang digunakan untuk ekstraksi adalah etanol $70 \%$. Bahan-bahan yang digunakan pada uji fitokimia adalah etanol, kloroform (Merck, Jerman), amoniak, $\mathrm{H}_{2} \mathrm{SO}_{4} 2 \mathrm{M}$, asam asetat anhidrida, $\mathrm{H}_{2} \mathrm{SO}_{4}$ pekat, serbuk magnesium, $\mathrm{HCl} 5 \mathrm{M}$, metanol, $\mathrm{NaCl} 10 \%, \mathrm{FeCl}_{3} 1 \%$, pereaksi Dragendorf, pereaksi Meyer, dan pereaksi Wagner. Bahan-bahan yang digunakan untuk uji total fenolik dan flavonoid adalah asam galat (JT Baker Chemical Co, Amerika Serikat), natrium karbonat (Merck, Jerman), Follin Ciocalteu (Merck, Jerman), kuersetin (Sigma-Aldrich, Amerika Serikat), metanol absolut (Merck, Jerman), etanol absolut (Merck, Jerman). Selain bahan-bahan yang telah disebutkan, untuk uji antioksidan dan antiinflamasi juga digunakan asam askorbat (HiMedia, India), 2,2-diphenyl-1-picrylhydrazyl atau DPPH (Sigma-Aldrich, Amerika Serikat), buffer Tris- $\mathrm{HCl} 1 \mathrm{M}$ (pH 7,4), darah segar sapi yang di dapatkan dari Rumah Potong Hewan PT Elders Indonesia, natrium diklofenak (PT. Novell Pharmaceutical Laboratories, Indonesia), larutan alsever, buffer natrium fosfat 0,15 M $(\mathrm{pH} 7,4)$, serta $\mathrm{NaCl} 0,25 \%$ dan $0,85 \%$.

\section{Pengeringan dan Ekstraksi Daun Belimbing Wuluh}

Daun belimbing wuluh diambil dari pohon, dikumpulkan, dan kemudian dicuci dengan air mengalir dan ditiriskan. Daun belimbing wuluh tersebut selanjutnya dikeringkan dalam oven pada suhu $50 \pm 3^{\circ} \mathrm{C}$ sampai kadar air kurang dari 10\%. Daun yang telah dikeringkan kemudian diblender kemudian diayak menggunakan saringan berukuran 60 mesh.

Metode ekstraksi yang digunakan adalah maserasi dengan perbandingan bahan dan pelarut (etanol 70\%) 1:10. Simplisia daun belimbing wuluh sebanyak 70 gram direndam dengan etanol $70 \%$ sebanyak $700 \mathrm{ml}$ selama 3 hari dan diaduk setiap 1 x24 jam selama 5 menit. Penyaringan dilakukan menggunakan vakum dan kertas saring untuk memisahkan ampas dan filtratnya. Filtrat yang didapat 
kemudian dipekatkan menggunakan rotary evaporator sampai pelarut habis menguap sehingga didapatkan ekstrak kental daun belimbing wuluh (Ibrahim et al., 2014).

\section{Skrining Fitokimia}

Karakteristik fitokimia dari ekstrak etanol daun belimbing wuluh diuji dengan mengacu pada metode Malik et al. (2017). Senyawa fitokimia yang diidentifikasi adalah alkaloid, saponin, flavonoid, tanin, steroid dan triterpenoid.

\section{Penentuan Kandungan Total Fenolik}

Penentuan kandungan total fenolik berdasarkan metode dari Demiray et al., 2009. Ekstrak daun belimbing wuluh dilarutkan dalam pelarut etanol $70 \%$ (1000 $\mu \mathrm{g} / \mathrm{ml}$ ). Sebanyak $1 \mathrm{ml}$ larutan sampel dicampur dengan $4 \mathrm{ml}$ larutan natrium karbonat $(75 \mathrm{~g} / \mathrm{l})$ dalam labu takar $10 \mathrm{ml}$, kemudian dikocok. Pereaksi FollinCiocalteu sebanyak $2 \mathrm{ml}$ dimasukkan ke dalam labu takar tersebut dan dikocok lagi. Setelah homogen, ke dalam campuran reaksi ditambahkan akuades hingga tanda tera. Campuran didiamkan dalam ruang gelap pada suhu kamar selama 1 jam, selanjutnya diukur absorbansinya pada panjang gelombang $760 \mathrm{~nm}$ menggunakan spektrofotometer (dengan tiga kali pengamatan/triplo). Sebagai standar digunakan larutan asam galat dengan berbagai konsentrasi $(0,20,40,60$, $80,100 \mu \mathrm{g} / \mathrm{ml})$. Total fenolik yang diperoleh dinyatakan sebagai ekivalen asam galat (GAE) dalam $\mu \mathrm{g}$ per miligram ekstrak kering

\section{Penentuan Kandungan Total Flavonoid}

Kandungan total flavonoid ekstrak daun belimbing wuluh mengacu pada Vongsak et al. (2013). Sebanyak 0,5 ml ekstrak daun belimbing wuluh (dalam metanol) konsentrasi $250 \mu \mathrm{g} / \mathrm{ml}$ ditambahkan dengan $0,5 \mathrm{ml} \mathrm{AlCl} 32 \%$. Larutan dihomogenkan dan diinkubasi selama 10 menit. Absorbansi diukur menggunakan spektrofotometer sinar tampak pada panjang gelombang $415 \mathrm{~nm}$ (triplo). Total flavonoid ekstrak daun belimbing wuluh dinyatakan sebagai $\mu \mathrm{g}$ kuersetin ekuivalen (QE) per miligram ekstrak kering. Kuersetin dengan berbagai konsenstrasi $(0,5,10,15,20,25,30$, $\mu \mathrm{g} / \mathrm{ml}$ ) digunakan sebagai standar.

\section{Uji Aktivitas Antioksidan}

Pengukuran aktivitas antioksidan (Vignoli et al., 2011) ekstrak etanol daun belimbing wuluh dilakukan menggunakan metode DPPH. Prinsip kerja metode ini adalah proses reduksi senyawa radikal bebas DPPH oleh antioksidan. Metanol $80 \%$ ditambahkan ke dalam ekstrak etanol daun belimbing wuluh untuk membuat larutan ekstrak dengan konsentrasi akhir 0, 1,25; 2,50; 3,$75 ; 5,00 ; 6.25 ; 7.50 \mu \mathrm{g} / \mathrm{ml}$. Sebanyak $0,3 \mathrm{ml}$ larutan ekstrak ditambahkan dengan $0,9 \mathrm{ml}$ campuran uji. Campuran uji terdiri dari larutan DPPH 0,4 mM, $1 \mathrm{M}$ buffer Tris- $\mathrm{HCl} \mathrm{pH} 7,4$, dan metanol $20 \%$ dengan rasio yang sama. Campuran dihomogenkan dan diinkubasi dalam ruang gelap selama 20 menit. Absorbansi diukur menggunakan spektrofotometer sinar tampak pada panjang gelombang $520 \mathrm{~nm}$ (triplo). Persentase inhibisi radikal DPPH dihitung dengan rumus $\left[\left(A_{0}-A_{1}\right) / A_{0}\right] \times 100$ dimana $A_{0}$ adalah absorbansi kontrol negatif sedangkan $A_{1}$ adalah absorbansi larutan ekstrak/kontrol positif. Kurva regresi hubungan antara konsentrasi ekstrak $(0,1,25 ; 2,50 ; 3,75 ; 5,00 ; 6,25 ; 7,5$ $\mu \mathrm{g} / \mathrm{ml})$ dan $\%$ inhibisi kemudian dibuat dan nilai $I_{50}$ dihitung menggunakan persamaan regresi yang dihasilkan, yaitu $y=9,1103 x-2,4973\left(R^{2}=0,9965\right)$. Asam askorbat digunakan sebagai kontrol positif.

\section{Uji Aktivitas Antiinflamasi}

Dalam penelitian ini pengujian aktivitas antiinflamasi dilakukan berdasarkan metode yang sudah dilakukan oleh Wiranto et al. (2016). Pertamatama, dilakukan preparasi suspensi sel darah merah sapi $10 \%$. Sampel darah dimasukkan ke dalam tabung sentrifugasi yang telah berisi larutan alsever dengan perbandingan yang sama, selanjutnya disentrifugasi dengan kecepatan $3000 \mathrm{rpm}$ selama 15 menit pada suhu ruang. Supernatan yang terbentuk dipisahkan dengan hati-hati dari sel darah merah menggunakan pipet tetes steril. Endapan sel-sel darah dicuci dengan larutan $\mathrm{NaCl} 0,85 \%$ dan disentrifugasi kembali. Proses pencucian dan sentrifugasi diulangi sebanyak lima kali sampai supernatan jernih. Volume sel darah merah diukur dan diresuspensi dengan larutan $\mathrm{NaCl}$ 0,85\% sehingga diperoleh konsentrasi suspensi sel darah merah $10 \%$.

Uji aktivitas antiinflamasi dimulai dengan mempersiapkan stok ekstrak etanol daun belimbing wuluh (dalam larutan isosalin) diencerkan dibuat konsentrasi berseri: 200, 300, 500 dan $600 \mu \mathrm{g} / \mathrm{ml}$. Larutan standar yang digunakan adalah natrium diklofenak (100 $\mu \mathrm{g} / \mathrm{ml})$. Campuran uji terdiri dari $2 \mathrm{ml}$ $\mathrm{NaCl} 0,25 \% ; 1 \mathrm{ml} \mathrm{0,15} \mathrm{M}$ buffer natrium fosfat $(\mathrm{pH} \mathrm{7,4);}$ $0,5 \mathrm{ml}$ suspensi sel darah merah sapi $10 \%$ dan $1 \mathrm{ml}$ ekstrak etanol daun belimbing wuluh atau larutan standar sebagai kontrol positifnya. Campuran uji diinkubasi pada suhu $56 \pm 3^{\circ} \mathrm{C}$ selama 30 menit, kemudian disentrifugasi dengan kecepatan 5000 rpm selama 10 menit. Bagian supernatannya diambil dan absorbansinya diukur pada panjang gelombang $560 \mathrm{~nm}$ (triplo). Persentase inhibisi hemolisis dihitung dengan rumus $\left[\left(A_{0}-A_{1}\right) / A_{0}\right] \times 100$ dimana $A_{0}$ adalah absorbansi kontrol negatif sedangkan $A_{1}$ adalah absorbansi larutan ekstrak/standar.

\section{Analisis Statistik}

Semua pengukuran dilakukan sebanyak 3 ulangan. Semua data kuantitatif ditampilkan sebagai rata-rata \pm standar deviasi (SD). Analisis data dilakukan menggunakan analisis deskriptif dan analisis perbandingan nilai rata-rata. Analisa perbandingan nilai rata-rata dilakukan dengan $u j i \mathrm{t}$ saling bebas dan ANOVA $(p<0,05)$ menggunakan program SPSS 21 .

\section{Hasil dan Pembahasan \\ Kandungan Fitokimia Ekstrak \\ Skrining fitokimia adalah tahap pendahuluan dalam suatu penelitian fitokimia yang bertujuan}


memberi gambaran mengenai golongan senyawa yang terkandung dalam tanaman yang diteliti (Simaremare, 2014). Hasil uji skrining fitokimia ini menunjukkan bahwa ekstrak etanol $70 \%$ daun belimbing wuluh mengandung beberapa senyawa metabolit sekunder seperti yang ditunjukkan pada Tabel 1. Hal tersebut sesuai dengan yang telah dikemukakan oleh Wijayanti dan Safitri (2018) bahwa selain tanin, daun belimbing wuluh juga mengandung senyawa flavonoid, saponin, sulfur, asam format,kalsium oksalat, dan kalium sitrat . Beberapa metabolit sekunder dilaporkan memiliki aktivitas farmakologis. Alkaloid dilaporkan memiliki aktivitas antikanker dan antivirus. Tanin juga mendapat banyak perhatian terutama pada bidang nutrisi, kesehatan, serta obat-obatan karena memiliki aktivitas fisiologis seperti antioksidan, antimikroba, dan antiinflamasi. Flavonoid termasuk kelompok polifenol adalah senyawa yang dapat menangkap radikal bebas,

Tabel 1. Analisis kualitatif senyawa fitokimia ekstrak etanol daun belimbing wuluh

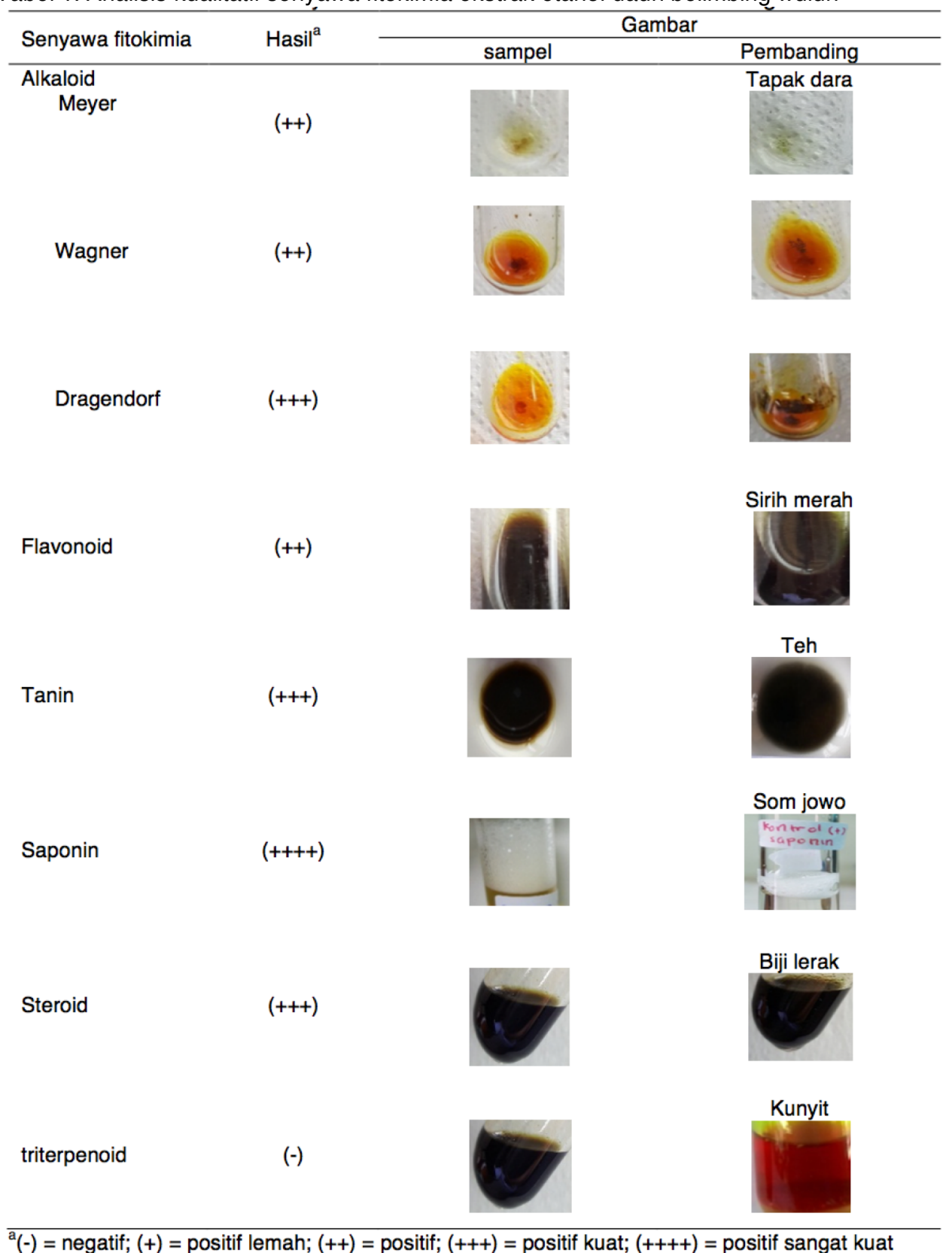

Tabel 2. Kandungan total fenolik dan flavonoid serta aktivitas antioksidan ekstrak etanol daun belimbing wuluh

\begin{tabular}{lccc}
\hline & \multicolumn{3}{c}{ Analisis Kuantitatif* } \\
\cline { 2 - 4 } Larutan Uji & $\begin{array}{c}\text { Total Fenolik } \\
(\mu \mathrm{g} \mathrm{GAE} / \mathrm{mg} \text { ekstrak) }\end{array}$ & $\begin{array}{c}\text { Total Flavonoid } \\
(\mu \mathrm{g} \mathrm{QE} / \mathrm{mg} \text { ekstrak })\end{array}$ & $\begin{array}{c}1 \mathrm{IC}_{50} \\
(\mu \mathrm{g} / \mathrm{ml})\end{array}$ \\
\hline $\begin{array}{l}\text { Ekstrak etanol daun } \\
\text { belimbing wuluh }\end{array}$ & $39,03 \pm 0,25$ & $97,28 \pm 0,25$ & $16,99 \pm 0,12^{\mathrm{a}}$ \\
$\begin{array}{l}\text { Asam askorbat (kontrol } \\
\text { positif aktivitas } \\
\text { antioksidan) }\end{array}$ & - & - & $5,71 \pm 0,04^{\mathrm{b}}$ \\
\hline
\end{tabular}

Nilai dinyatakan dalam rata-rata $\pm S D$; nilai merupakan rata-rata dari 3 ulangan pengukuran

${ }^{a}$ Nilai dalam satu kolom yang sama diikuti oleh huruf kecil yang berbeda menunjukkan perbedaan nyata $(p<0,05)$ 
berperan sebagai super antioksidan yang juga memiliki aktivitas antiinflamasi, mencegah kerusakan oksidatif sel, serta memiliki aktivitas antikanker yang kuat (Valsan dan Raphael, 2016). Steroid diduga memiliki efek peningkat stamina tubuh dan antiinflamasi (Nurjanah et al., 2011). Sementara saponin dapat memberikan efek antitusif dan ekspektoran yang dapat menyembuhkan batuk. Saponin juga memiliki aktivitas antiinflamasi karena telah terbukti dapat menghambat pelepasan zat-zat proinflamasi yang distimulasi oleh lipopolisakarida (Lee et al., 2015)

\section{Kandungan Total Fenolik dan Flavonoid}

Uji kandungan total fenol dilakukan untuk mengetahui jumlah fenol yang terdapat pada ekstrak daun belimbing wuluh. Uji ini dilakukan dengan metode Follin Ciocalteu. Prinsip dari metode Follin Ciocalteu adalah terbentuknya senyawa kompleks berwarna biru yang dapat diukur pada panjang gelombang $765 \mathrm{~nm}$. Pereaksi tersebut mengoksidasi fenolat (garam alkali) atau gugus fenolik hidroksi mereduksi asam heteropoli (fosfomolibdat-fosfotungsat) yang terdapat dalam pereaksi Follin Ciocalteu menjadi suatu kompleks molibdenum-tungsten. Senyawa fenolik bereaksi dengan Follin Ciocalteu hanya dalam suasana basa agar terjadi disosiasi proton pada senyawa fenolik menjadi ion fenolat. Kondisi basa tersebut dibuat dengan menggunakan $\mathrm{NaCO}_{3} 7,5 \%$ (Alfian dan Susanti, 2012). Kandungan total fenolik dan flavonoid ekstrak etanol daun belimbing wuluh disajikan pada Tabel 2. Nilai total fenolik dinyatakan dalam $\mu \mathrm{g}$ ekivalen asam galat per mg ekstrak sedangkan nilai total flavonoid dinyatakan dalam $\mu$ g ekivalen kuersetin per mg ekstrak.

Gugus hidroksil pada senyawa fenolik bereaksi dengan reagen Follin Ciocalteu membentuk molibdenum tungsten berwarna biru yang dapat dideteksi dengan spektrofotometer. Semakin besar konsentrasi senyawa fenolik maka semakin banyak ion fenolat yang dapat mereduksi asam heteropoli (fosfomolibdat-fosfotungsat) menjadi kompleks molibdenum-tungsten sehingga warna biru yang dihasilkan semakin pekat (Alfian dan Susanti, 2012). Asam galat termasuk dalam senyawa fenolik turunan asam hidroksibenzoat yang tergolong asam fenolik sederhana menurut Tahir et al. (2017) dan merupakan salah satu asam fenolik yang banyak terdapat dalam tumbuhan (Fiuza et al., 2014).

Kandungan total fenolik ekstrak etanol daun belimbing wuluh (Tabel 2) lebih tinggi jika dibandingkan dengan total fenolik ekstrak etanol daun alpukat sebesar 10,72 $\mu \mathrm{g}$ GAE/mg ekstrak (Widarta dan Anarta 2017). Namun jika dibandingkan dengan ekstrak etanol daun samama (Anthocephalus macrophylus) yang memiliki kandungan total fenolik sebesar 210,22 mg GAE/g ekstrak berdasarkan penelitian yang dilakukan oleh Ikram et al. (2017) dan ekstrak metanol buah belimbing wuluh sebesar 65,16 $\mu \mathrm{g}$ GAE/mg berdasarkan penelitian yang dilakukan oleh Hasanuzzaman et al. (2013), maka ekstrak etanol daun belimbing wuluh memiliki kandungan total fenolik lebih rendah.
Senyawa fenolik merupakan metabolit sekunder yang ditemukan tersebar di beberapa bagian tanaman yang memiliki aktivitas biologis seperti antibakteri, antiinflamasi, antitrombotik, antivirus, hepatoprotektif, antikanker dan antialergi serta seringkali dikaitkan dengan mekanisme kerjanya sebagai antioksidan (Hoelz et al., 2010). Senyawa fenolik bersifat esensial untuk pertumbuhan dan reproduksi tanaman sebagai respon pertahanan terhadap patogen dan kondisi stres pada tanaman (Yordi et al., 2012). Senyawa fenolik merupakan pemberi warna, rasa, dan aroma yang spesifik pada bagian tanaman tertentu, seperti antosianin sebagai pigmen warna merah dan ungu pada anggur, eugenol sebagai pemberi aroma pada pisang, dan flavanon yang menyebabkan rasa pahit yang kelarutannya secara umum adalah dalam pelarut organik polar, sementara bentuk glikosidanya dapat larut dalam air (Yordi et al., 2012).

Penentuan kadar flavonoid menggunakan metode kolorimetri dengan penambahan pereaksi $\mathrm{AlCl}_{3}$. Pereaksi ini dapat membentuk reaksi dengan golongan flavonoid membentuk kompleks antara gugus hidroksil dan keton yang berdampingan dan dapat bereaksi dengan gugus keton pada $\mathrm{C}_{4}$ serta gugus $\mathrm{OH}$ pada $\mathrm{C}_{3}$ atau $\mathrm{C}_{5}$ pada senyawa flavon/flavonol yang membentuk senyawa berwarna kuning. Kuersetin digunakan sebagai standar pada penentuan kadar flavonoid dalam penelitian ini, karena kuersetin merupakan flavonoid golongan flavonol yang memiliki gugus keton pada atom $\mathrm{C}_{4}$ dan juga gugus hidroksil pada atom $\mathrm{C}_{3}$ dan $\mathrm{C}_{5}$ yang berdampingan (Azizah et al., 2014). Kadar flavonoid ekstrak etanol daun belimbing wuluh (Tabel 2) lebih tinggi dibandingkan ekstrak etanol daun nangka yang memiliki kadar flavonoid sebesar 4,22 mg/g ekstrak (Adnyani et al., 2017), dan ekstrak etanol sambiloto, yaitu 46,32 g/kg ekstrak (Rais, 2015). Flavonoid merupakan senyawa fenolik yang paling banyak ditemukan dalam tanaman (Yordi et al., 2012). Sejumlah tanaman obat yang mengandung flavonoid telah dilaporkan memiliki aktivitas antioksidan, antibakteri, antivirus, antiradang, antialergi, dan antikanker (Ahmad et al., 2015).

\section{Aktivitas Antioksidan}

Parameter yang digunakan untuk pengukuran aktivitas antioksidan ekstrak etanol daun belimbing wuluh adalah nilai $\mathrm{IC}_{50}$ (Inhibitor Concentration 50\%) yang menyatakan besarnya konsentrasi larutan sampel yang dibutuhkan untuk mereduksi radikal bebas DPPH sebesar 50\% (Nurjanah et al., 2011). Semakin kecil nilai $\mathrm{IC} 50$ berarti semakin tinggi aktivitas antioksidannya. Aktivitas antioksidan dari suatu senyawa dapat digolongkan berdasarkan nilai $\mathrm{IC}_{50}$ yang diperoleh. Jika nilai $I_{50}$ suatu ekstrak berada dibawah 50 ppm maka aktivitas antioksidannya sangat kuat, nilai $\mathrm{IC}_{50}$ berada diantar 50-100 ppm berarti aktivitas antioksidannya kuat, nilai $\mathrm{IC}_{50}$ berada diantara 101-150 ppm berarti aktivitas antioksidannya sedang, nilai $I_{50}$ berada diantara 151-200 ppm berarti aktivitas antioksidannya lemah, sementara apabila nilai $\mathrm{IC}_{50}$ berada diatas 200 
ppm maka aktivitas antioksidannya sangat lemah (Salim, 2018).

Hasil pengujian aktivitas antioksidan menunjukkan bahwa asam askorbat sebagai kontrol positif memiliki nilai $\mathrm{IC}_{50}$ sebesar $5,71 \pm 0,04 \mu \mathrm{g} / \mathrm{ml}$, sementara esktrak etanol daun belimbing wuluh memiliki nilai $\mathrm{IC}_{50}$ sebesar $16,99 \pm 0,12 \mu \mathrm{g} / \mathrm{ml}$ (Tabel 2). Ekstrak etanol daun belimbing wuluh memiliki aktivitas antioksidan yang lebih tinggi dibandingkan fraksi eter dan air ekstrak metanol buah belimbing wuluh memiiki nilai $I_{50}$ berturut-turut sebesar 50,36 dan 44,01 ppm. Ekstrak etanol daun belimbing wuluh juga memiliki aktivitas antioksidan yang lebih tinggi dibandingkan ekstrak etanol daun stroberi ( $\left.\mathrm{IC}_{50} 363,55 \mathrm{ppm}\right)$ menurut Widyastuti et al. (2016), ekstrak etanol daun bangunbangun ( $\left(\mathrm{IC}_{50} 59,26 \mathrm{ppm}\right)$ menurut Surya et al. (2013), dan infusa daun wungu ( IC $_{50}$ 125,09 ppm) berdasarkan penelitian yang dilakukan Salim (2018).

Hasil uji t saling bebas menunjukkan bahwa $\mathrm{IC}_{50}$ ekstrak etanol daun belimbing wuluh berbeda secara signifikan dengan rata-rata nilai $\mathrm{IC}_{50}$ asam askorbat. Meskipun begitu keduanya sama-sama memiliki aktivitas antioksidan yang tergolong sangat kuat. Metode uji DPPH merupakan metode pengujian aktivitas antioksidan yang paling sesuai bagi komponen antioksidan yang bersifat polar, karena kristal DPPH hanya dapat larut dan memberikan absorbansi maksimum pada pelarut seperti etanol ataupun metanol (Nurjanah et al., 2011).

Umumnya senyawa-senyawa yang memiliki aktivitas antioksidan adalah senyawa fenol karena mempunyai gugus hidroksi yang terdistribusi pada posisi ortho dan para terhadap gugus $-\mathrm{OH}$ dan $-\mathrm{OR}$. Perubahan warna DPPH terjadi karena adanya senyawa yang dapat memberikan radikal hidrogen kepada radikal DPPH sehingga tereduksi menjadi DPPH-H (1.2-difenil-2-pikrilhidrazin) (Purwaningsih, 2012). Flavonoid merupakan antioksidan yang potensial sebagai penangkap radikal bebas, pengkelat logam, dan penghambat oksidasi lemak karena memiliki struktur yang terdiri dari grup hidroksil pada karbon ketiga, memiliki ikatan ganda antara karbon kedua dan ketiga, posisi karbon keempat terdapat grup karbonil serta polihidroksilasi pada cincin aromatik A dan B (Purwaningsih, 2012).

\section{Aktivitas Antiinflamasi}

Sel darah merah atau eritrosit telah banyak digunakan sebagai suatu model untuk mempelajari interaksi antara obat dan membran dan stabilisasi membran sel darah merah oleh suatu senyawa yang dapat mencegah peristiwa hemolisis dapat dijadikan tolok ukur berbagai senyawa yang memiliki aktivitas antiinflamasi (Kumar, 2012). Kontrol positif yang digunakan dalam pengukuran aktivitas antiinflamasi ini adalah natrium diklofenak dan aktivitas antiinflamasi pada metode ini dinyatakan dengan persen inhibisi hemolisis. Natrium diklofenak (100 $\mu \mathrm{g} / \mathrm{mL})$ memiliki aktivitas antiinflamasi yang ditunjukkan dengan nilai persen inhibisi hemolisisnya sebesar 89,62 $\pm 2,57 \%$. Ekstrak etanol daun belimbing wuluh memiliki aktivitas antiinflamasi pada konsentrasi 200, 300, 500, 600 $\mu \mathrm{g} / \mathrm{ml}$ yang ditunjukkan dengan nilai persen inhibisinya secara berturut-turut sebesar $91,18 \pm 4,62 ; 81,42 \pm 2,55$; $84,26 \pm 1,05$; dan 50,49 $\pm 13,27 \%$ (Figur 2).

Ekstrak yang memiliki aktivitas antiinflamasi terlihat dari penurunan absorbansi hemoglobin yang terdeteksi pada campuran larutan uji, yaitu semakin kecilnya absorbansi yang terdeteksi pada campuran larutan uji berarti membran sel darah merah semakin stabil dan sedikit mengalami lisis (Wiranto et al., 2016). Hasil uji ANOVA menunjukkan bahwa konsentrasi ekstrak etanol daun belimbing wuluh pada 600 ppm memiliki nilai persen inhibisi yang paling rendah serta berbeda signifikan $(p<0,05)$ dibandingkan dengan konsentrasi pada 200,300, 500 ppm dan konsentrasi natrium diklofenak.

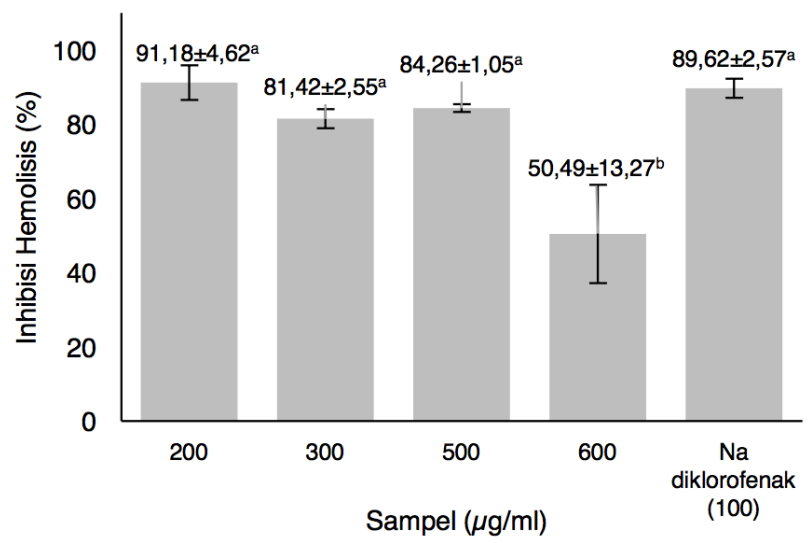

Figur 1. Rata-rata persentase inhibisi hemolisis sel darah merah dari ekstrak dan kontrol positif natrium diklofenak terhadap induksi panas dan larutan hipotonik. Nilai dinyatakan dalam rata-rata $\pm S D$. Nilai yang diikuti oleh huruf kecil yang berbeda menunjukkan perbedaan nyata $(p<0,05)$

Konsentrasi ekstrak berpengaruh terhadap nilai persen inhibisi hemolisisnya. Konsentrasi ekstrak etanol daun belimbing wuluh 200 ppm memiliki nilai persen inhibisi hemolisis paling tinggi dibandingkan dengan konsentrasi ekstrak lainnya (Figur 1). Konsentrasi ekstrak 200 ppm ini merupakan konsentrasi ekstrak terendah yang diujikan. Obat herbal dalam dosis tinggi diketahui dapat menyebabkan pelepasan histamin secara langsung dari sel mast sehingga mengakibatkan pembuluh darah menjadi lebih permeabel terhadap cairan plasma dan menimbulkan proses peradangan (Rinayanti et al., 2014). Hal tersebut diduga menjadi penyebab rendahnya persen inhibisi hemolisis yang dihasilkan oleh ekstrak etanol daun belimbing wuluh pada konsentrasi 600 ppm.

Beberapa penelitian menunjukkan bahwa triterpenoid berkaitan dengan stabilitas membran (Radhika et al., 2002). Senyawa triterpenoid dari ligustrum memiliki kemampuan menghambat aktivitas enzim siklooksigenase dalam mengkonversi asam arakhidonat menjadi prostaglandin sebagai mediator inflamasi (Wu et al., 2011). Hasil penelitian yang dilakukan Chippada et al. (2011) juga menunjukkan bahwa senyawa flavonoid dan triterpenoid dari ekstrak Cintella asiatica bertanggung jawab terhadap aktivitas 
antiinflamasi dalam menstabilkan membran sel darah merah. Aktivitas antiinflamasi saponin dari berbagai tumbuhan sudah banyak dilaporkan, namun mengenai mekanisme kerja secara pasti dari saponin sebagai antiinflamasi belum banyak diketahui. Saponin terdiri dari steroid atau gugus triterpen (aglikon) yang mempunyai aksi seperti detergen yang diduga mampu berinteraksi dengan banyak membran lipid seperti fosfolipid yang merupakan prekursor prostaglandin dan mediator-mediator inflamasi lainnya sehingga dapat berfungsi sebagai antiinflamasi (Hidayati et al., 2008)

\section{Kesimpulan}

Senyawa fitokimia yang terkandung dalam ekstrak etanol daun belimbing wuluh telah berhasil diidentifikasi yang meliputi saponin, tanin, steroid, flavonoid dan alkoloid. Kadar total fenol dan flavonoid ekstrak daun belimbing wuluh dapat ditentukan dan berpotensi menjadi salah satu sumber antioksidan dan antiinflamasi alami, karena memiliki aktivitas antioksidan yang tergolong sangat kuat serta menunjukkan adanya aktivitas antiinflamasi.

\section{Daftar Pustaka}

Adnyani, N.M.R.D., Parwata, I.M.O.A., Negara, I.M.S. 2017. Potensi ekstrak daun nangka (Artocarpus heterophyllus Lam.) sebagai antioksidan alami. Jurnal Kimia 10(2):162-167. DOI:10.24843/JCHEM.2017.v11.i02.p10.

Agustina, R., Indrawati, D.T., Masruhin, M.A. 2015. Aktivitas ekstrak daun salam (Eugenia poyantha) sebagai antiinflamasi pada tikus putih (Rattus novergicus). Journal of Tropical Pharmacy and Chemistry 3(2):120-123. DOI: 10.25026/jtpc.v $3 \mathrm{i} 2.96$.

Ahmad, A.R., Juwita, Ratulangi, S.A.D., Malik, A. 2015. Penetapan kadar fenolik dan flavonoid total ekstrak metanol buah dan daun patikala (Etlingera elatior (Jack) R.M.SM). Pharmaceutical Sciences and Research, 2(1):1-10. DOI:10.7454/psr.v2i1.3481.

Alfian, R., Susanti, H. 2012. Penetapan kadar fenolik total ekstrak metanol kelopak bunga rosella merah (Hibiscus sabdariffa Linn) dengan variasi tempat tumbuh secara spektrofotometri. Pharmaciana Jurnal Kefarmasian, 2(1):73-80. DOI:10.12928/pharmaciana.v2i1.655.

Astuti, S. 2008. Isoflavon kedelai dan potensinya sebagai penangkap radikal bebas. Jurnal Teknologi dan Industri Hasil Pertanian 13(2):126136.

Azizah, D.N., Kumolowati, E., Faramayuda, F. 2014. Penetapan kadar flavonoid metodel $\mathrm{AlCl}_{3}$ pada ekstrak metanol kulit buah kakaon (Theobroma cacao L.). Kartika Jurnal IImiah Farmasi 2(2):4549. DOI:10.26874/kjif.v2i2.14.

Chippada, S.C., Volluri, S.S., Bammidi, S.R., Vangalapati, M. 2011. In vitro anti inflammatory activity of methanolic extract of Centella asiatica by HRBC membrane stabilisation. Rasayan
Journal of Chemistry

$4(2): 457-460$

DOI:10.13005/bbra/867.

Fiuza, S.M., Gomes, C., Teixeira, Girao, M.T., Cordeiro, M.N.D.S., Milhazes, N., Borges, F., Marques, M.P.M. 2004. Phenolic acid derivatives with potensial anticancer properties a structure activity relationship study part 1: methyl, propyl, and octyl esters of caffeic and gallic acids. Bioorganic and Medical Chemistry 12(13):3581-3589. DOI:10.1016/j.bmc.2004.04.026.

Hasanuzzaman, M., Ali, M.R., Hossain, M., Kuri, S., Islam, M.S. 2013. Evaluation total phenolic content, free radical scavenging activity and phytochemical screening of different extracts of Averrhoa bilimbi (frutis). International Current Pharmaceutical Journal 2(4):92-96. DOI:10.3329/ icpj.v2i4.14058.

Hidayati, N.A., Listyawati, S., Setyawan, A.D. 2008. Kandungan kimia dan uji antiinflamasi ekstrak etanol Lantana camara L. pada tikus putih (Rattus norvegicus L.) jantan. Bioteknologi 5(1):10-17. DOl:10.13057/biotek/c050102.

Hoelz, L.V.B., Horta, B.A.C., Araujo, J.Q., Albuquerque, G., Alencastro, R.B., Silva, J.F. 2010. Quantitative structure activity relationships of antioxidant phenolic compounds. Journal of Chemical dan Pharmaceutical Research 2(5):291-306.

Ibrahim, N., Yusriadi, Ihwan. 2014. Uji efek antipiretik kombinasi ekstrak etanol herba sambiloto (Andrographis paniculata Burm.f. Nees.) dan ekstrak etanol daun belimbing wuluh (Averrhoa bilimbi L.) pada tikus putih jantan (Rattus novergicus). Online Journal of Natural Science FMIPA 3(3):257-268.

Ikram, K., Jayali, A.M., Umar, S., Sasamita, I. 2017. Penentuan total fenolik dan aktivitas antioksidan ekstrak etanolik daun samama (Anthocephalus macrophylus) asal Ternate, Maluku Utara. Jurnal Kimia Mulawarman, 15(1):11-15. DOI:10.30872/ jkm.v15i1495.

Kemenkes RI. 2012. Buletin Jendela Data dan Informasi Kesehatan, topik Penyakit Tidak Menular. Kementerian Kesehatan Republik Indonesia.

Kumar, V., Bhat, Z.A., Kumar, D., Khan, N.A., Chashoo, I.A., Shah, M.Y. 2012. Evaluation of antiinflammatory potensial of petal extracts of Crocus sativus "cashmerianus". International Journal of Phytopharmacy 3(1):27-31. DOI:10.13140/RG.2.2.18813.67048.

Lee, Y.Y., Park, J., Lee, E., Lee, S., Kim, D., Kang, J.L., Kim, H. 2015. Anti-inflammatory mechanism of ginseng saponin metabolite Rh3 in lipopolysaccharide-stimulated microglia: critical role of 5'-adenosine monophosphate-activated protein kinase signaling pathway. Journal of Agricultural and Food Chemistry 63:3472-3480. DOI:10.1021/jf506110y.

Martono, B., Setiyono, R.T. 2014. Skrining fitokimia enam genotipe teh. Jurnal Tanaman Industri dan 
Penyegar, 1(2):63-68. DOI:10.21082/jtidp. v1n2.2014.p63-68.

Mujib, A., Ilah, A., Aslam, J., Fatima, S., Siddiqui, Z.H., Maqsood, M. 2012. Catharanthus roseus alkaloids: application of biotechnology for improving yield. Journal of Plant Growth Regulation 68(2):111-127. DOI: 10.1007/s10725012-9704-4.

Nurjanah, Izzati, L., Abdullah, A. 2011. Aktivitas antioksidan dan komponen bioaktif kerang pisau (Solen spp.). Jurnal Ilmu Kelautan 16(3):119-124.

Purwaningsih, S., Salamah, E., Sukarno, A.Y.P., Deskawati. 2013. Aktivitas antioksidan dari buah mangrove (Rhizophora muronata Lamk.) pada suhu yang berbeda. Jurnal Pengolahan Hasil Perikanan Indonesia 16(3):199-206.

Radhika, P., Anjaneyulu, V., Rao, P.V.S., Makareiva, T.N., Kalinovosky, A.I. 2002. Chemical examination of the Echinoderms of Indian Ocean: The triterpene glycosides of the sea cucumber. Holothuria nobilis, Bohadschia aff. tenuissima and Actinopyga mauritana from Lakshadweep, Andaman and Nicobar Islands. Indian Journal of Chemistry 41B(6):1276-1282.

Rais, I.R. 2015. Isolasi dan penentuan kadar flavonoid ekstrak etanolik herba sambiloto (Andrographis paniculata (Burm. F.) Ness. Pharmaciana 5(1):101-106. DOI:10.12928/pharmaciana.v5i1. 2292.

Rinayanti, A., Dewanti, E., Adelina, M.H. 2014. Uji efek antiinflamasi fraksi air daun mahkota dewa (Phaleria macrocarpa (Shecff.) Boerl.) terhadap tikus putih (Rattus norvegicus L.). Pharmaceutical Sciences and Reseach 1(2):7885. DOI:10.7454/psr.v1i2.3324.

Salim, R. 2018. Uji aktivitas antioksidan infusa daun ungu dengan metode DPPH (1,1-dipehnil-2picrylhidrazil). Jurnal Katalisator 3(2):153-161. DOI:10.22216/jk.v3i2.3372.

Sangi, M.S., Momuat, L.I., Kumaunang. 2012. Uji toksisitas dan skrining fitokimia tepung gabah pelepah aren (Arenga pinnata). Jurnal IImiah Sains 12(2):128-134.

Setyani, W., Setyowati, H., Ayuningtyas, D. 2016. Pemanfaatan ekstrak terstandarisasi daun som jowo (Talinum paniculatum (Jacq.) Gaertn) dalam sediaan krim antibakteri Staphylococcus aereus. Jurnal Farmasi Sains dan Komunitas 13(1):4451. DOI:10.24071/jpsc.131139.

Simaremare, E.S. 2014. Skrining fitokimia ekstrak etanol daun gatal (Laportea decumana (Roxb.) Wedd). Pharmacy 11(1):98-107.

Surya, A., Jose, C., Teruna, H.Y. 2013. Studi aktivitas antioksidan dari ekstrak metanol dan etil asetat pada daun bangun-bangun (Plectranthus amboinicus). Jurnal Indonesia Chemia Acta 4(1):12-16.

Tahir, M., Mufihunna, A., Syafrianti. 2017. Penentuan kadar fenolik total ekstrak etanol daun nilam (Pogostemon cablin Benth.) dengan metode spektrofotometri UV-Vis. Jurnal Fitofarmaka
Indonesia $\quad 4(1): 215-218 . \quad$ DOI:10.33096/jffi. v4i1.231.

Thomas, A.N.S. 2007. Tanaman Obat Tradisional 2. Kanisius, Yogyakarta.

Valsan, A., Raphael, R.K. 2016. Pharmacognostic profile of Averrhoa bilimbi Linn. Leaves. South Indian Journal of Biological Science 2(1):75-80. DOI:10.22205/sijbs/2016/v2/i1/100347.

Vignoli, J.A., Bassoli, D. G., Benassi, M. T. 2011. Antioxidant activity, polyphenols, caffeine and melanoidins in soluble coffee: the influence of processing conditions and raw material. Food Chemistry 124:863-868. DOI:10.1016/ j.foodchem.2010.07.008.

Vinoid, K.S., Raghuveer, I., Alok, S.H.G. 2010. Phytochemical investigation and chromatographic evaluation of the ethanolic extract of whole plant extract of Dendrophthoe falcata (L.F.) Ettingsh. International Journal of Pharmaceutical Sciences and Research 1: 39-45.

Vongsak, B., Sithisarn, P., Mangmool, S., Thongpraditchote, S., Wongkrajang, Y., Gritsanapan, W. 2013. Maximizing total phenolics, total flavonoids content and antioxidant activity of Moringa oleifera leaf extract by the appropriate extraction method. Industrial Crops and Products 44:566-571. DOI: 10.1016/j.indcrop.2012.09.021.

WHO. 2014. Global status report on noncommunicable. World Health Organization.

Widarta, I.W.R., Arnata, I.W. 2017. Ekstraksi komponen bioaktif daun alpukat dengan bantuan ultrasonik pada berbagai jenis dan konsentrasi pelarut. Agritech (3)2:148-157. DOI:10.22146/agritech. 10397.

Widyastuti, Kusuma, A.E., Nurlaili, Sukmawati. 2016. Aktivitas antioksidan dan tabir surya ekstrak etanol daun stroberi (Fragaria $x$ ananassa A.N. Duchesne). Jurnal Sains dan Farmasi Klinis 3(1):19-24. DOI:10.25077/jsfk.3.1.19-24.2016.

Wijayanti T.R.A., Safitri R. 2018. Uji aktivitas antibakteri ekstrak daun belimbing wuluh (Averrhoa bilimbi Linn) terhadap pertumbuhan bakteri Staphylococcus aureus penyebab infeksi nifas. Jurnal IImiah IImu Kesehatan 6(3):277-285. DOI:10.33366/cr.v6i3.999.

Wiranto, E., Wibowo, M.A., Ardiningsih, P. 2016. Aktivitas antiinflamasi secara in vitro ekstrak teripang butoh keling (Holothuria leucospilota Brandt) dari pulau lemukutan. Jurnal Kimia Kathulistiwa 5(1):52-57.

Wu, J., Yi, Y.H., Tang, H.F., Wu, H.M., Zhou, Z.R. 2007. Hillasides $A$ and $B$, two new cytotoic triterpene glicosides from the sea cucumber Holothuria hilla lesson. Journal of Asian Natural Products Reseach 9(7):609-615. DOI:10.1080/ 10286020600882676.

Yordi, E.G., Perez, E.M., Matos, M.J., Villares, E.U. 2012. Nutrition, Well-Being and Health. Bouayed J, Bohn T, editor. INTECH, London. 